\title{
A Study on Characteristics of China's Government Reform in Different Stages since the Reform and Opening-Up and Its Prospects
}

\author{
Fangcheng Yuan \\ Institute of Political Science, Huazhong Normal University, Wuhan, Hubei 430079 \\ E-mail: yuanfangcheng@yahoo.cn
}

\begin{abstract}
Government reform is not only the current and important issues of public concern, but also a common task that most countries must face. Based on the study of objectives, contents and characteristics of government reform in various stages in China since the reform and opening-up, this article focuses on the analysis of the essentials, characteristics and implications of government reform. The mid- to long-term development trend of government reform in the future is put forward accordingly.
\end{abstract}

Keywords: Government reform, Characteristics in different stages, Prospects

The government reform is always an important part of China's political system reform. In "Government Work Report" made by Premier Wen Jiabao in the Eleventh National People's Congress, it states clearly that: "...to speed up the administrative system reform and enhance the Government's own construction." Government reform has attracted considerable public concern. In fact, with the socialist market system improved constantly since the reform and opening-up, China's current government reforms have gone through several stages, showing different characteristics in different historical periods. This is of great value in our grasping and understanding of the basic trends of China's government reform and in promoting its reforms and developments in the future.

\section{The process and characteristics of China's government reform in different stages}

In the early 1980s, Deng Xiaoping, the chief designer of China's reform, made the famous statement: "Institutional reform is revolution". During the past thirty years, we have fully changed the development model from the socialist planned economy to the market economy. Centering on how to set up a suitable government system to the development of China's socialist market system, China has carried out five government reforms. The background and theme of each previous reforms of government's institutions varies. Their results are also difficult to be generalized, since they should be placed in a specific historical background and historical conditions to be examined. However, on the whole, the previous government reforms have achieved remarkable success and also taught us valuable lessons. Summarizing and evaluating the lessons of previous reforms rationally is very necessary for the new round of government reforms which just started. Evaluating the gains and losses of the past reforms accurately is beneficial to government reforms to continue to advance along the existing basis, and to promoting the current new round of reform to achieve new breakthroughs.

Insert Table 1 Here.

Looking back to the previous government reforms in China since the reform and opening-up, we can see the good combination of theoretical innovation and practical exploration, favorable experiences and useful models of government reform: First, the institutional reform: gradually changing from government functions under the planned economic system, canceling special economic management departments and strengthening relevant government agencies in charge of macro management, market supervision and public service; Second, the department establishment: great legal process. From the central to local government levels, departments have implemented the "three fixed" scheme, which is fixed functions, statutory body, setting a quota. In promoting the process of the legal system of the government departments, staff establishing has been significantly streamlined. Institutional reforms in 1998 witnesses the greatest reducing of personnel, about one half of the State Council members by reassigning personnel. These five reforms help reducing financial burden at all levels and improving the work efficiency of government; Third, in the construction of civil servants, in accordance with the requirements of building a high-quality and professional national civil service, we deepen the reform of personnel system, introduce the competitive mechanism, and improve the civil service system. gradually The country have introduced the "Regulations on Selecting and Appointing Leading Party and Government Cadres", as well as rules and methods on national civil service evaluation, rewards, serving evasion and avoidance of official business, job rotation, publicity before their appointment." Since January 1, 2006, Civil Servant Law of the People's Republic of China "has been taken into effect. The introduction of these regulatory measures has effectively promoted the civil service system with Chinese characteristics to become more mature. 
On the whole, along with the establishment and perfection of the socialist market economic system, China's political restructuring get its characteristics gradually, and the past several government reforms also have certain transitional and intermittent characteristics, but each time the reform achievements are difficult to be consolidated lastingly and they can't fundamentally get rid of the circulation of "simplification - - inflation - - re-simplification again - - re-inflation". At present, many divergences and problems remain in the government reform with some deep-level problems becoming more acute and obvious. Firstly, the transformation of government functions is still not thorough. The coordination of internal relations among different government organization and the reasonability of the organizational structure exert crucial impact on the realization of the government function. After previous reforms, the government function of overall allocation can still hardly meet the requirements of the evolving socialist market economy and the public finance system has not been fully established. . Moreover, the government also undertakes a large number of matters which should not be in its charge, not be able to manage or manage well. Secondly, the establishment of government institution is always arbitrary. In the process of government reform, institutions always change whenever the leadership changes, or whenever the leaders change their views; The administrative action of agency management is actually arbitrary, for the local governments at all levels often create empty jobs, set up empty situations and adjusting institutional establishment arbitrarily; Thirdly, pursuit of the interests of government departments and units for their own set back substantive progress of government's reform. The huge potential of public power makes the government put their public benefits first as their target, such as getting a promotion and gaining greater right. Fourth, government functions in decision-making and implementation are not divided, the policy-making and consultation system is not perfect, and the administrative law enforcement system is imperfect. At present, our country's administrative law-enforcing departments are numerous, but of disperse, chaotic and unreasonable management, which cause unhealthy power-benefit and benefit-law relations.

\section{Super-Ministry System: The current government reform’s innovative exploration}

With the deepening of market economy system reform, the government function and the organization establishment require subsequent change. The long-awaited Super-Ministry System reform program of the State Council has been approved and implemented by the First Session of the Tenth National People's Congress this year. Based on transformation of government function and clarification of duties of various government departments, it begins a new round of reform of exploring organic and unified Super-Ministry system of all functions through rationalizing distributing functions of macro-control department in order to improve people's living standard as a key point, and conformity social management and the public services department.

The Super-Ministry System, referring to the government at all levels enlarging horizontal coverage on organization establishment, integrating departments of close or related functions into a super ministry as far as possible. Ministry management is mainly on macro aspects, formulating strategies and providing policy. The preposition of Super-Ministry System has distinctive features of its age. The past several government reforms, although emphasizing the transformation of government function, in reality, put emphasis on simplifying structure and improving administrative efficiency. However, the main goal of this organization reform is transform the government model from economic construction-type and administrative control -type to service-type and public administrative government under established social market system

On a international scale, the appearance of the Super-Ministry System does not only meet the requirement of economic and social development of government management, but also is very necessary for efficient government work. As for the advantages of the super-ministry system, the White Paper "Reorganization of the Central Government" which is published by the Heath government in October, 1970, had explained it in detail. Looking from England and France's practice, the biggest advantage of the Super-Ministry System are as follows: related business is submitted to one ministry and gains effective coordination; centralized governance help reduce dispute among separate departments and problems can be easily solved; business staff could be reduced and human resources disposed to front-line business.

In our country, carrying out the Super-Ministry System has many obvious advantages. First, it is beneficial to solve various problems existing in our country's government institution setting. At present, because of our country's government institutions are too complicated, management objects and the administration are overlapped. In addition, organizational overlapping, function overlapping and coordination difficulties are also very popular, and all these problems become the difficulties and focal point of government function transformation and institution reform in China. The implement of the Super-Ministry System serves as a new breakthrough to optimize government institution establishment and function deployment in our country.

Second, it is beneficial to break department barrier and department monopoly and to centralizing and integrating all kinds of resources. According to the Parkinson's law, there exists self expanding trend in administrative function department and employee number and this malady is very common. Carrying out the Super-Ministry System is helpful to people, poverty, resources flowing in a larger department rather than bad competition among previous departments, and it keeps different sectors from taking the internal resources as in a cage. 
Third, it is beneficial to strengthen macro-management to cope with realistic social problems. The problem of ecological environment, differentiation of wealth, social emergency crisis and so on need to be solved from a global aspect and with strategic thinking. Implement of the Super-Ministry System is benefit to different government departments making comprehensive decision and getting rid of executive, technical, and service affairs. At the same time, because of the Super-Ministry System narrows down management range of the government, thus government has much more time and energy to decision-making, improving government's integration ability of macro-control.

Fourth, it is beneficial to developing socialist market economy. At present, our government department seems too huge when compared with western developed countries. Implementing the Super-Ministry System, as an organic integration and reconstruction of the original several departments, could avoid many original disadvantages. It is favorable to consolidating the government's status as micro economic subject under market economy, and to government function changes further. Therefore, implementing the Super-Ministry System helps to continuously overcome a variety of disadvantages of the current system, and create good system atmosphere and environment for the economic and social development of our country.

But on the other hand, the Super-Ministry System reform may create new problems while helping solve many problems. One is that the reform pressure may be gathered to the administrative department officer. The Super-Ministry System reform involves benefits of many department and personal benefits. Reform needs to cut and merge some departments from the original ones, especially the benefit departments. This will absolutely influence the benefits of some departments, which will be the biggest resistances and difficulties to the reform. Meanwhile, reform will increase the administrative span of the department chief officer, so department heads will strengthen the supervision and control of his subordinate units and staff. Benefit drives the government power to a smaller scale, thus puts more challenges to the leadership and supervision ability of department chiefs.

The second problem is that the difficulty and cost of internal coordinative may rise rapidly. Along with the increase of inside component units of super-ministry, coordination task of department inside will also increase. At the same time, the Super-Ministry System is a kind of new system, and each unite division needs to experience a running-in period and establish cooperative relations among each other. If Super-Ministry fails in this running-in period and coordinate the contradiction promptly, it will most possibly and necessarily be separated. Our department has experienced "on and off" periods and it also happened in foreign countries. For example, Britain held Super-Ministry System reform in 1960-1970, at that time, the environment department merged many departments and become the super large department of British government, but due to internal coordination difficulties, it was forced to separate.

Thirdly, the contradictory relationship between central and local governments may aggravate. In accordance with the original system design, the relationships among the various functional departments of the central government are between segmentation and constraints of power. After the implementation of Super-Ministry System, this type of segmentation and friction are gone. The new construct ministry's management power and range has greatly extended. At the same time, it means that the central government department has more power and range to manage and control the local, while the local government will have more chance and frequency controlled or intervened by the central government, thus the enthusiasm of the local will greatly influenced. Obviously, it will lead to a new round power game between central government and local governments, but in the process of game lacking legalized and programmed, the possibility of friction and contradiction will be greatly increased.

Fourthly, lacking scientific planning of departments integration, it may lower government governance performance. The success of the super-ministry system reform is not measured by the degree of functional sectors simplification and the separation between decision-making bodies and executive bodies. Actually, setting up government organization is influenced by many factors, such as history and reality. In our country, government departments number, decision-making bodies and executive bodies must be made according to our situation and modernization process, such as the number and quality of current social public business and public demand, the development and mature degree of civil society and government governance ability. Therefore, due to numerous public businesses, huge public demands, lower integration degree, limited social autonomy ability, immature development, and low department leading level, cooperative consciousness and inability, blind combination without scientific planning may lead to the loss of government authority, damage of government public trust, and more resistance and difficulty in improving government public governance performance.

\section{Prospecting Development Trend of China's Government Reform}

Taking a wide view of the whole process of government reform since China's reform and opening-up, the experiences and lessons are of great importance to promotion of our government reform and governance in the future. To sum up, the current reform has accumulated some basic experience: First, we must insist on having socialist market economic system as the first aim, put the transformation of government functions as a key government reform; Second, we must adhere to the principle of simplification, unification and efficiency, streamlining and optimizing the organizational structure of the government as the central task of government reform; Third, we must adhere to the principle actively, 
steadily and unswervingly towards the pace of reform, but also give full consideration to all aspects of the extent of affordable, prudent advance; Fourth, we must adhere to institutional reform and the reform of personnel system combined to develop complementary policies and measurements to optimize the cadre structure; Fifth, we must adhere to a unified leadership and grade responsibility, and analysis of the truth from the reality, then carry out reforms step by step according to local conditions.

Each reform of government institutions under certain historical conditions are the products of subjective and objective results of the interaction between history and reality. The present proposition and process of Super-Ministry System reform is also based on the complex interaction of subjective and objective, history and reality factors as well as drawing on the experiences of foreign governments on major reforms. It can be expected that the future government reforms will face more complicated environment and conditions and will bear more distinctive characteristics of the times and trends.

First, the government reform will increasingly focus on support and promotion of innovation theory. Mill proposed in "Representative Government", the main principles which the service department set should be the establishment of the executive branch to handle the administrative unity of purpose and a means-based. In the past, China's institutional reform was always carried out under the pressure which was compelled by the situation from a policy point and always lacked of a more systematic and rational, forward-looking theory to guide practical reform. The reform of government institutions is a complicated systematic project, to promote reform of government institutions to success. First, we must actively promote relevant theoretical innovation. In the future, one important base to promote the reform of the government is from the perspective of clarifying the relationship between government reforms and market economy development and between institutional innovations and government capacity improvement. At the same time the government reforms should be deepened from full functional government to limited functional one; from administrative government to law-oriented government; and from a closed government to transparent government. And we should also deepen the understanding of the relationship between government and the market, and between the government and society, putting forward new concept of building the Government's new public service. We must change from government-oriented management to public-oriented services, from government standard, official standard system to social standard and people standard system.

Secondly, the Government reform will increasingly focus on legislation. Due to the lack of effective legal constraints and high arbitrary and subjectivity in the past successive reforms in China, the government often trapped in the cycle of "simplification - inflation- re-simplification - re-inflation ", the results achieved in the reform are often quickly lost. Therefore, the legalization of institution reform is the key point in the current and future reforms. To realize this, it is imperative to conduct a comprehensive and systematic change or necessary addition to the existing laws and regulations according to the international requirements. We need to modify and improve the "Organic Law of the State Council" and the Local Government Organization Act, make laws on establishing conditions, approval procedures, task nature, inter-relationship among executive authorities and their responsibilities, authority, division of functions and the exercise of powers a basic form of duties. Meanwhile, we should establish the appropriate accountability system to ensure that the various violation of law punishable be dealt with according to law, if necessary, to the decision of institutional reform laws made by the NPC Standing Committee.

Third, government reform will increasingly focus on its functions as the core proposition. Government functions are the basis for government institutions, while government agencies are the carrier of government functions. As the basis and prerequisite of government organizations, government functions decide the establishment, scale, level and operation mode of the government agencies. In implementing "super-ministry system" as well as the future reform, we must combine transformation of government functions with government institutions reform. Transformation of government functions is the basis and conditions of smooth implementation of super-ministry system. International experience shows that the more developed decentralized public governance structures, the more successful the government reform will be. Otherwise, super-ministry system will become dysfunctional. However, only by truly carrying out the transformation of government functions can government's institutional reform get rid of the "simplification - inflationre-simplification - re-inflation" cycle. Practice has proved that in a complex society, the fundamental solution is to explore effective coordination mechanisms which will be a difficult and long-term task.

Finally, the Government will increasingly emphasize on institutional reform and comprehensive reform. The reform in the past is ineffective, the main reason of which is that they are only limited within the established system of partial adjustment of the government agencies within the system, only change in the size and number of personnel but without actual institutional reforms. If we want to successfully promote government reform, we need a systematic and comprehensive consideration of development costs and benefits. The promotion of reform can not be accomplished over night, deepening the reform is an ongoing process which involves complex relationships and power relations in the interests. It must adhere to the principles of the reform package as a whole, so that most of the reform and other reform should be coherent and mutually promoting. It is now particularly important to accelerate the reform of public 
institutions category, innovative delivery mechanisms of public goods and attach importance to public welfare institutions in the provision of public goods and public services. In accordance with the principle of public affairs separating from government and government separating from intermediary organizations, the government must grant a large number of technical and service functions to the institutions and intermediary organizations; standardize and develop trade associations, chambers of commerce and other social intermediary organizations to provide a good social environment for the transformation of government functions.

In short, the government system is the joint points which connects the economic system, political system and social system and is the key links to push forwards the whole reforms. China has already acquired the basic practical conditions for the transition from a government under planned economy to a modern government under the market economy after 30 years' reform and opening-up makes. However, government reform still faces great difficulties of power-oriented, benefit-oriented department now and in the future. "Super-ministry reform is a new beginning for our government reform, and government stitutional reform and innovation is of great importance to the gradual realization of the organic and comprehension combined governance of the government, market and social organizations.

\section{References}

Yun Yu. (2007). Continue to promote the restructuring of government departments-special visit to Tang Tiehan, researcher, assistant dean of China National School of Administration .New Horizon.

Hua Xu. (2003). Legislate department organization law, deepen reform in government institutions. China Reform News.

Xuerong Tao, Rui Tao. (2006). Research reform of administrative system in China. Beijing: Peoples Publishing House.pp. 155

Jingpeng Li. (2005). Review and reflection: experiences and lessons of government institutional restructuring. China Public Administration, 19.

Fulin Chi. (2008).The super ministry should making big things. New Times Weekly.

Jiang Wu. (2005).The history experience of our country's government institutional restructuring. China Public Administration.

J.S.Mill. Representative Government. Beijing: Commercial Publishing House

Xiangguo Cheng, Yi Han. (2007). International tide of new public management and administrative reform. Beijing: Peoples Publishing House 
Table 1. Since the reform and opening up of the previous Government Reform

\begin{tabular}{|c|c|c|c|}
\hline TIME & TARGET & CONTENT & CHARACTERISTICS \\
\hline 1982 & $\begin{array}{l}\text { Solve the leadership system } \\
\text { issues in the process of } \\
\text { economic development , } \\
\text { enforce cadres to become } \\
\text { younger in average age }\end{array}$ & $\begin{array}{l}\text { Ministries and Commissions under the } \\
\text { State Council, Organizations directly } \\
\text { under the State Council, office under } \\
\text { the State Council are reduced from } 100 \\
\text { to } 61 .\end{array}$ & $\begin{array}{l}\text { First, start to abolish the system of life } \\
\text { tenure in leading posts; Second, simplify } \\
\text { the administrative structure; Third, } \\
\text { Accelerate the ranks of cadres younger } \\
\text { in average age. But did not move high } \\
\text { degree of concentration planned } \\
\text { economy system, the government's } \\
\text { functions has not transformed. }\end{array}$ \\
\hline 1988 & $\begin{array}{l}\text { Accelerating the } \\
\text { transformation of government } \\
\text { functions, Government's } \\
\text { management of economy } \\
\text { department transformed } \\
\text { primarily from the direct } \\
\text { management into the indirect } \\
\text { supervision, strengthening } \\
\text { macroscopic management } \\
\text { function but abating the } \\
\text { micromanagement function. }\end{array}$ & $\begin{array}{l}\text { Ministries and Commissions under the } \\
\text { State Council reduced from } 45 \text { to } 41 \text {, } \\
\text { Organizations directly under the State } \\
\text { Council from } 22 \text { to } 19 \text {, non-standing } \\
\text { body reduced from } 75 \text { to } 44 \text {, the } \\
\text { subordinate departments and bureaus } \\
\text { reduced by } 20 \%\end{array}$ & $\begin{array}{l}\text { The historical contribution was firstly } \\
\text { proposed that the transformation of } \\
\text { government function is the key to } \\
\text { institutional reform. As a result of a } \\
\text { series of complex political and } \\
\text { economic reasons, in reality this } \\
\text { proposition have not solved later }\end{array}$ \\
\hline 1993 & $\begin{array}{l}\text { In accordance with the } \\
\text { requirements of the socialist } \\
\text { market economy to transform } \\
\text { government functions }\end{array}$ & $\begin{array}{l}\text { Ministries and Commissions under the } \\
\text { State Council established 41,adding to } \\
18 \text { offices and institutions, in all } \\
59 \text {,reduced } 27 \text { from the original } 86 \text {, and } \\
\text { the staff reduced } 20 \% \text {. Implements the } \\
\text { Central Commission for Inspecting } \\
\text { Discipline institution and the ministry } \\
\text { of supervision jointly work, and further } \\
\text { rationalize the relationship between the } \\
\text { discipline inspection and administrative } \\
\text { supervision. }\end{array}$ & $\begin{array}{l}\text { The historical contribution was firstly } \\
\text { proposed the purpose of the } \\
\text { restructuring of government institutions } \\
\text { to meet the requirements of an evolving } \\
\text { socialist market economy }\end{array}$ \\
\hline 1998 & $\begin{array}{l}\text { Eliminating the organization } \\
\text { foundation of the functions of } \\
\text { the government and } \\
\text { enterprises mixed up }\end{array}$ & $\begin{array}{l}\text { According to the reform program, } \\
\text { Ministries and Commissions under the } \\
\text { State Council reduced from } 40 \text { to } \\
\text { 29.After 1999, provincial government } \\
\text { and the party's institutional reforms } \\
\text { were launched separately; 2000, City } \\
\text { county township corporate reform were } \\
\text { comprehensive started. Up to June, } \\
\text { 2002, Party and government organs at } \\
\text { all levels altogether simplify the } \\
\text { administration to establish 1,150,000 } \\
\text { people. }\end{array}$ & $\begin{array}{l}\text { This involves the most extensive and the } \\
\text { biggest reform of government } \\
\text { institutions. The historical progress lies } \\
\text { in the transformation of government } \\
\text { functions have made the significant } \\
\text { development, the prominently } \\
\text { manifestation is abolished nearly all of } \\
\text { the industry-specific economic agencies. }\end{array}$ \\
\hline 2003 & $\begin{array}{lr}\text { Featuring } & \text { standardized } \\
\text { behaviors, } & \text { coordinated } \\
\text { operation, fairness and } & \text { and } \\
\text { transparency, honesty } & \text { and } \\
\text { high efficiency }\end{array}$ & $\begin{array}{l}\text { Except for the General Office of the } \\
\text { State Council, Ministries and } \\
\text { Commissions under the State Council } \\
\text { reduced from } 29 \text { to } 28 \text {, eliminating } \\
\text { MOFTEC, the State Economic and } \\
\text { Trade Commission, and their function } \\
\text { merge into new established the Board } \\
\text { of Trade. }\end{array}$ & $\begin{array}{l}\text { The significant historical progress lay in } \\
\text { holds at that time the socio-economic } \\
\text { development stage prominent question, } \\
\text { further transformed the government } \\
\text { function. }\end{array}$ \\
\hline
\end{tabular}

